\title{
Anterior rehabilitation involving dental bleaching, frenectomy and composite resin: a case report
}

\author{
Reabilitação anterior envolvendo clareamento dental, \\ frenectomia e resina composta: um relato de caso
}

\author{
Frederico dos Reis GOYATÁ1 1 iD https://orcid.org/0000-0002-7877-2188 \\ Luis Henrique Garcia MARQUES1 1 iD https://orcid.org/0000-0001-6829-3952 \\ Amália MORENO1 ID https://orcid.org/0000-0002-3474-2091 \\ Ivan Doche BARREIROS1 iD https://orcid.org/0000-0003-4335-7846 \\ João Batista NOVAES JÚNIOR' ${ }^{1}$ iD https://orcid.org/0000-0003-0502-1989 \\ Sávio Morato de Lacerda GONTIJO1 (iD https://orcid.org/0000-0002-7803-4345
}

\begin{abstract}
This clinical report describes the treatment of a patient dissatisfied with the esthetics of the smile due to the presence of narrow teeth, yellow and the presence of diastema between teeth 11 and 21. Clinical examination revealed absence of the disocclusion guides. The treatment plan consisted in obtaining study casts, assembly in a semi-adjustable articulator and diagnostic waxing, to evaluate the possibilities of a restorative treatment. After the approved the viability of the procedure, dental bleaching was started in-office with $38 \%$ hydrogen peroxide associated with at-home bleaching with 15\% carbamide peroxide, in order to reduce the yellowing of the teeth. Afterwards, the functional evaluation of the restorative procedure was carried out through the prior preparation of the mock-up. After functional approval of the mock-up, lip frenectomy was performed, since the frenulum is the cause of the diastema between the teeth 11 and 21. After 4 weeks was carried out the restorative procedure of teeth 13 to 23 , with direct composite resin, improving the aesthetics of the smile and restoring the disocclusion guides.
\end{abstract}

Indexing terms: Dentistry. Esthetics, Dental. Oral rehabilitation

\section{RESUMO}

Este relatório clínico descreve o tratamento de um paciente insatisfeito com a estética do sorriso devido à presença de dentes estreitos, amarelados e à presença de diastema entre os dentes 11 e 21 . O exame clínico revelou ausência das guias de desoclusão. O plano de tratamento consistiu na obtenção de modelos de estudo, montagem em um articulador semi-ajustável e enceramento diagnóstico, para avaliar as possibilidades de um tratamento restaurador. Após a aprovação da viabilidade do procedimento, o clareamento dental foi iniciado em consultório, com 38\% de peróxido de hidrogênio, associado ao clareamento caseiro, com 15\% de peróxido de carbamida, a fim de reduzir o amarelamento dos dentes. Posteriormente, a avaliação funcional do procedimento restaurador foi

$\checkmark \nabla \nabla$

1 Universidade Federal de Minas Gerais, Faculdade de Odontologia, Departamento de Clínica, Patologia e Cirurgias Odontológicas. Av. Presidente Antônio Carlos, 6627, CEP 31270-901, Belo Horizonte, MG, Brasil. Correspondence to: SML GONTIJO. E-mail: <savio.morato@yahoo.com.br>.

$\boldsymbol{\nabla} \nabla \boldsymbol{v}$

How to cite this article

Goyatá FR, Marques LHG, Moreno A, Barreiros ID, Novaes Júnior JB, Gontijo SML. Anterior rehabilitation involving dental bleaching, frenectomy and composite resin: a case report. RGO, Rev Gaúch Odontol. 2020;68: e20200032. http://dx.doi.org/10.1590/1981863720200003220190015 
realizada através da preparação prévia do mock-up. Após aprovação funcional do mock-up, foi realizada a frenectomia labial, uma vez que o freio era a causa do diastema entre os dentes 11 e 21 . Após 4 semanas, foi realizado o procedimento restaurador dos dentes 13 ao 23, com resina composta direta, melhorando a estética do sorriso e restaurando as guias de desoclusão.

Termos de indexação: Odontologia. Estética dentária. Reabilitação bucal.

\section{INTRODUCTION}

Changes in color and dental shape may compromise the beautiful of the smile and interfere with self-esteem and social interaction [1]. In this sense, the esthetic parameters dictated by society have led patients to seek a "perfect" dental-facial harmony [2].

In the search for a more beautiful smile, dental bleaching has become popular for the treatment of yellow teeth, involving fast and efficient at-home and in-office methods [3]. Another factor that negatively affects the esthetics of anterior teeth is the presence of dental diastemas, characterized by increased interdental space [1]. The etiology of diastemas is varied and abnormal insertions of the frenulum can be a cause, meaning that lip frenectomy is often necessary [4]. Composite resins can be used to close these interdental spaces by remodeling the shape and size of the teeth, with minimal or no dental wear [5-8]. Among the various resin options present in the market, the micro-hybrid has good mechanical properties, with particles of size between 0.5 and $3.0 \mu \mathrm{m}$, being indicated for both anterior and posterior teeth [9]. These composite resins allow stratified restorations due to the wide variety of colors, with translucent and opaque material and resinous dyes that can reproduce the details and anatomical aspects present in natural teeth $[5,6,8]$.

The present case report describes esthetic smile rehabilitation through dental bleaching, associated with lip frenectomy, closure of a diastema and esthetic and functional remodeling from teeth 13 to 23 using a direct restorative technique with composite resin.

\section{CASE REPORT}

A 27-year-old male patient visited the Integrated Clinic of the Faculty of Dentistry of the Federal University of Minas Gerais (UFMG) dissatisfied with the esthetics of his smile due to the narrow and yellow teeth.

Clinical examination showed that the patient presented absence of the anterior, right and left lateral guides, and diastema between teeth 11 and 21 due to the low insertion of the upper lip frenulum (figure 1).

Treatment was initiated with prophylaxis of the teeth with an abrasive rubber (Kerr, Orange, CA, USA) and pumice stone (Kerr, Orange, CA, USA) and water, followed by isolation of the operative field with a photopolymerizable gingival barrier (OpalDam ${ }^{\circledR}$; Ultradent, South Jordan, UT, USA) and dental bleaching with $38 \%$ hydrogen peroxide gel (Opalescence ${ }^{\circledR}$ Xtra boost; Ultradent, South Jordan, UT, USA). The color change of the maxillary canines was assessed using the Vita Bleachedguide 3D Master scale (Vita-Zahnfabrik, Bad Säckingen, Germany). The shade of the teeth before bleaching was $3 \mathrm{M} 2$. The bleaching gel was applied to the buccal surface of the upper and lower teeth from the second premolar to the second premolar, in two 15-min procedure (figure 2). Concurrently with in-office bleaching, the patient was instructed to use a $15 \%$ carbamide peroxide gel (Opalescence ${ }^{\circledR}$ PF; Ultradent, South Jordan, UT, USA) for 4 hours a day for 30 days with weekly follow-up. The shade of the teeth after bleaching was $1 \mathrm{M} 2$. After bleaching, the teeth were polished to eliminate the presence of possible bleaching residues, and a topical application of neutral sodium fluoride (Ultradent, South Jordan, UT, USA) was performed for 4 min to reduce the sensitivity. After bleaching, a period of 8 weeks was
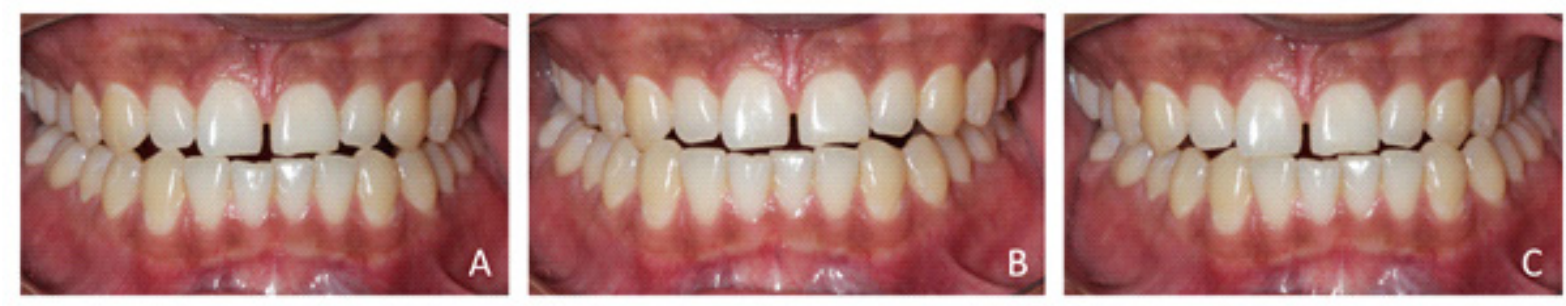

Figure 1. Absence of disocclusion guides. (A) Absence of the anterior, (B) right lateral and (C) left lateral disocclusion guides. $260 \times 51 \mathrm{~mm}(299 \times 299 \mathrm{DPI})$. 

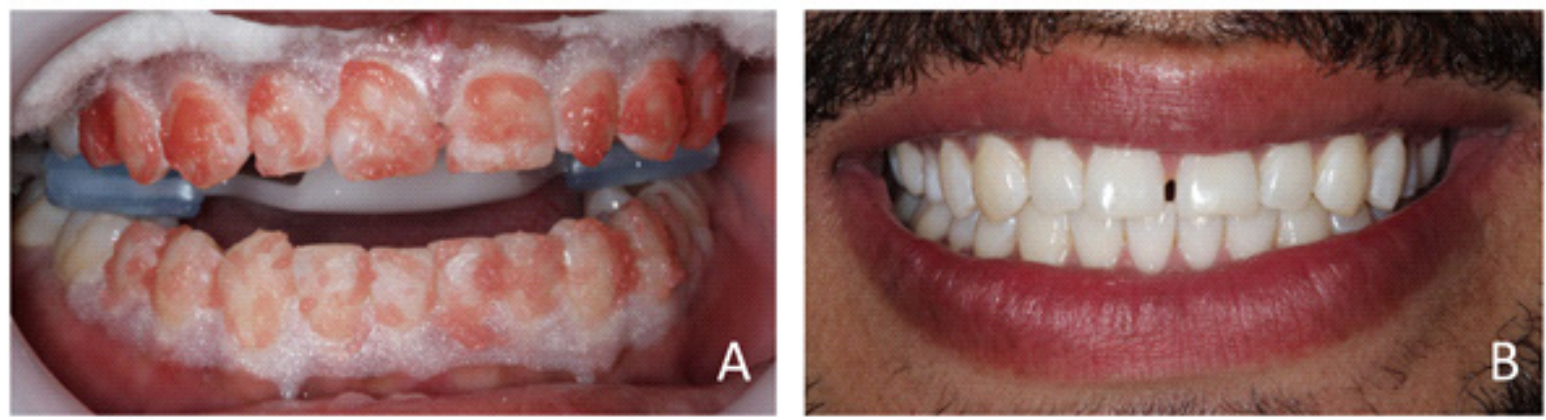

Figure 2. Dental bleaching. (A) 38\% hydrogen peroxide gel applied on the vestibular surface of the upper and lower teeth from the second premolar to the second premolar. (B) Smile after dental bleaching. 175x49mm (300 x $300 \mathrm{DPI})$.

waited before restorative procedures could be performed. This time is considered sufficient for the bleaching agents not to interfere in the bond strength of the composite restorations to the dentin tissue, to further stabilize the coloration obtained and to frenectomy healing [10].

A functional evaluation of the restorative procedure was carried out using a mock-up of bisacrylic resin (Structur ${ }^{\circledast}$ 3; Voco, Indian Land, SC, USA) for 7 days, obtained from a condensation silicone molding (Optosil ${ }^{\circledR}$; Heraeus, Hanau, HE, Germany) of the diagnostic waxing of the upper and lower casts mounted on a semi-adjustable articulator (Dentflex, Ribeirão Preto, SP, Brazil) (figure 3). These procedures were performed after dental bleaching.

After functional approval of the mock-up, a lip frenectomy was performed. This technique consisted of an incision that included the removal of frenulum, interdental tissues and the palatal papilla (Miller's technique) [11]. Briefly, the area was anesthetized with local infiltration using 2\% lidocaine with 1:100.000 epinephrine. The frenulum was pinched with hemostatic and incisions were made around that. The triangular tissue resected was removed with the hemostat (figure $4 \mathrm{~A}$ ). The wound was
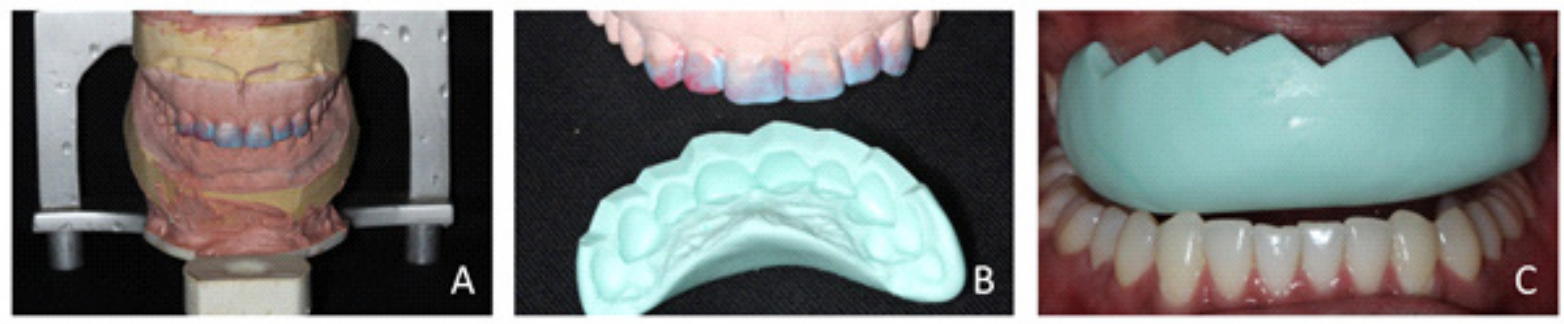

Figure 3. Treatment planning with waxing diagnosis and mock-up. (A) Diagnostic waxing mounted on a semiadjustable articulator. (B) Silicone condensation index obtained from diagnostic waxing. (C) Silicone mould in position. $243 \times 52 \mathrm{~mm}$ (300 × 300 DPI).
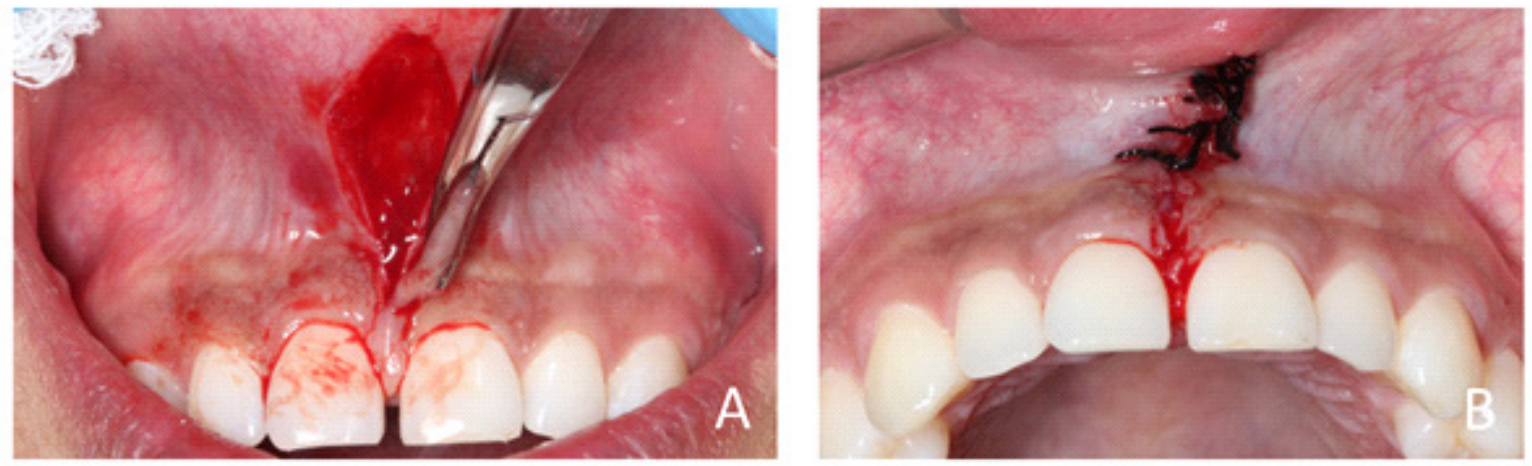

Figure 4. Upper labial frenectomy. (A) Surgical technique to remove the upper lip frenulum. (B) Photograph after removal of the upper lip frenulum. $164 \times 53 \mathrm{~mm}$ $(300 \times 300 \mathrm{DPI})$. 
sutured with 4-0 silk (figure 4B). The suture was removed after 7 days.

The restorative procedure was then initiated 4 weeks after lip frenectomy. A simplified rubber-dam technique was used [12]. Prophylaxis of the teeth with a pumice stone (Kerr, Orange, CA, USA) and water, acid etching of dental enamel with $37 \%$ phosphoric acid (Ultra-Etch ${ }^{\circledR}$, Ultradent, South Jordan, UT, USA) for $30 \mathrm{~s}$, rinse with water for $60 \mathrm{~s}$, enamel drying, application of the adhesive system (Peak ${ }^{\circledR}$; Ultradent, South Jordan, UT, USA) were performed according to the manufacturer's instructions [13]. The bonding agent was applied in two layers with microbrush and gently agitated for $10 \mathrm{~s}$, followed by thinning/drying for $10 \mathrm{~s}$ using $1 / 4$ to $1 / 2$ air pressure and then by light curing for $20 \mathrm{~s}$ (Fig. 5A, B).

After light curing of the adhesive system, the incremental insertion of the composite resin was started. Firstly, with the aid of the silicone condensation index, the composite resin was inserted using the TI color (Trans Ice) (Vitalescence ${ }^{\circledR}$; Ultradent, South Jordan, UT, USA) for the palatal enamel (Fig. 5C). Once the palatine face was restored, a higher opacity resin, A1 dentin (Vitalescence ${ }^{\circledR}$; Ultradent, South Jordan, UT, USA), was applied to reproduce the dentin. Finally, portions of composite resin related to buccal enamel in TF color (Trans Frost) (Vitalescence ${ }^{\circledR}$; Ultradent, South Jordan, UT, USA) were inserted for reproduction of the dental shape according to the diagnostic waxing.
Immediately after the restorative procedure, excess composite resin was removed with a \#12 scalpel blade and FF diamond tips (Komet, Rock Hill, SC, USA), followed by initial finishing with abrasive tips (Jiffy ${ }^{\circledR}$ System; Ultradent, South Jordan, UT, USA), and checking of the occlusal contacts and the disocclusion guides (figure 6).

After 7 days, polishing was performed with diamond polishing brushes (Jiffy® Brush; Ultradent, South Jordan, UT, USA) and 1 and $0.5 \mu \mathrm{m}$ granulation polishing pastes applied with a felt wool disc (Ultradent, South Jordan, UT, USA). The final result can be seen in figure 7 .

\section{DISCUSSION}

The pattern of esthetics and facial beauty are highly valued by society [2]. Yellow teeth that are worn and with the presence of diastema compromise the esthetics of the smile and affect individual self-esteem [1,5-8]. In the present case we describe how to achieve an improvement in the esthetic and functional harmony of the smile through dental bleaching, lip frenectomy and diastema closure with direct composite resin.

Dental bleaching is an important treatment option for yellowing teeth [3]. The advantages of associating in-office and at-home bleaching method is a faster result [14]. In
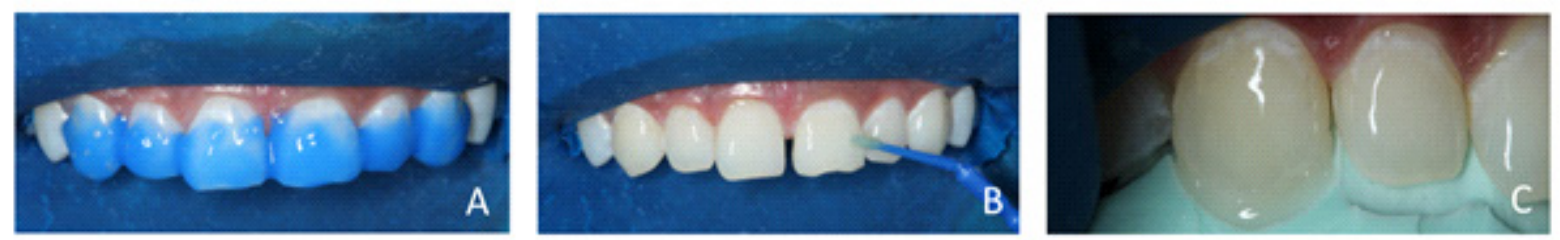

Figure 5. Esthetic and functional remodeling of the smile. (A) Etch-and-rise. (B) Application of adhesive system. (C) Incremental insertion of the composite resin using the silicone condensation index. 252x40mm (300 x $300 \mathrm{DPI})$.
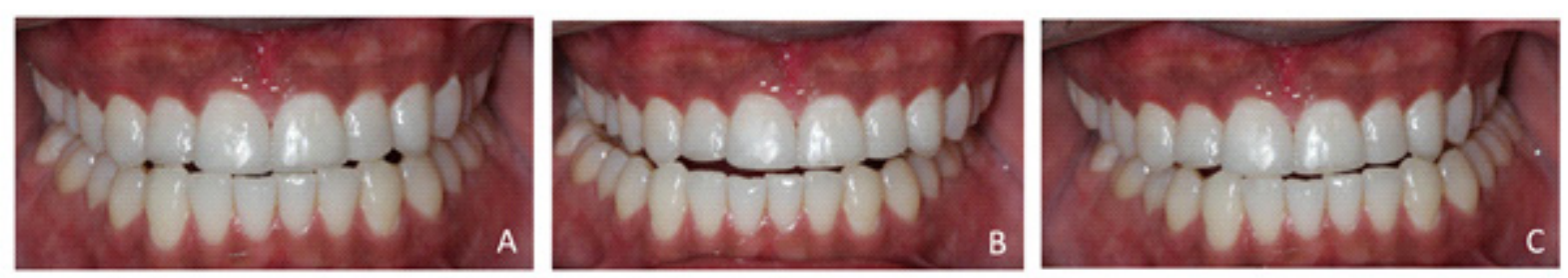

Figure 6. Disocclusion guides. (A) Anterior, (B) right lateral and (C) left lateral disocclusion guides, after esthetic and functional remodeling of the smile. $297 \times 52 \mathrm{~mm}(262 \times 262 \mathrm{DPI})$. 

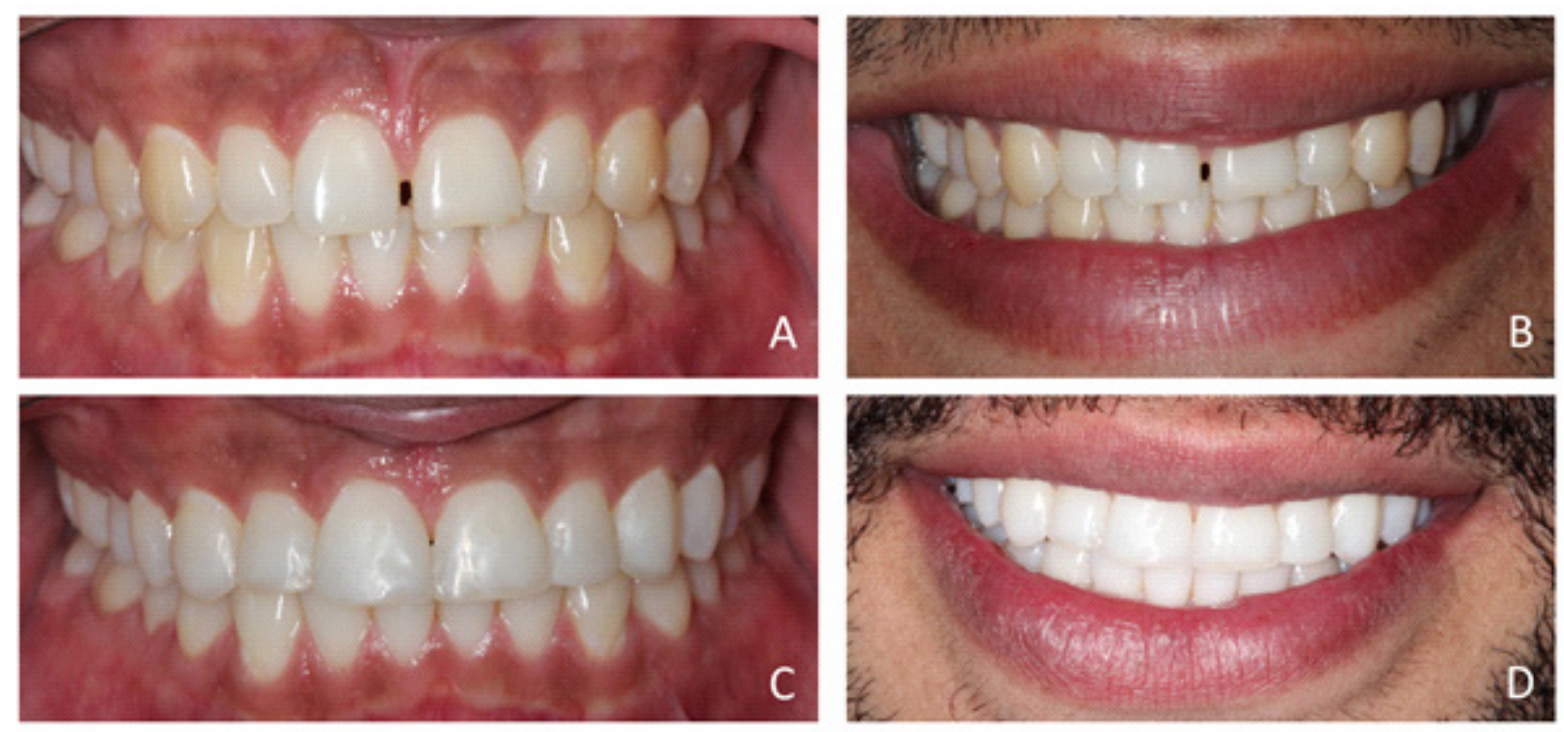

Figure 7. Initial and final pictures to check the difference. (A and B) Initial clinical case. (C and D) Final clinical case. 212x99mm (300 x 300 DPI).

the present case, dental bleaching was planned with the objective of improving the esthetic result of the composite resins, thus increasing the value of the teeth to be restored.

In order to carry out the restorative procedure it was first necessary to evaluate esthetically and functionally the procedure to be performed. A diagnostic waxing was thus performed and the casts were mounted onto a semi-adjustable articulator and the mock-up preparation for the clinical evaluation of the disocclusion guides.

After esthetic and functional approval of the mock-up, lip frenectomy was performed, followed by restorative procedures.

Frequently the cause of diastemas between the central incisors is the low insertion of the frenulum. This can be assessed when the upper lip is elevated, leaving the region of the interincisive papilla ischemic. Therefore, in order to allow the closing of the diastema without compression of the interdental papilla, it is necessary to perform the frenectomy [15].

The recommendation for an adhesive procedure on bleached enamel is to wait for stabilization of the result and to allow the release of any residual oxygen $[16,17]$.

The excellent potential of composite resins to restore esthetics with longevity supports their use in the reestablishment of the disocclusion guides, as well as in the closure of diastema $[5-8,18,19]$. When compared to the indirect technique, this approach has the advantage of being less invasive and cheaper $[6,7,19]$. The main advantages of the indirect technique would be polymerization contraction occurring outside the mouth, better color stability, less amount of residual polymer, less marginal infiltration, better physical properties and more durability [20]. However, this technique requires expulsive preparation, often leading to wear of the healthy dental structure, in addition to requires more clinical session [21]. Due to the need for wear and tear of the healthy dental structure and higher cost of indirect technique, was chose for the direct technique.

In the present case the option for esthetic remodeling of the six anterior teeth in the upper arch allowed the restoration of function and esthetics in a simple and effective way, preserving the healthy dental structure to the maximum, with ideal relationships in terms of shape, proportion, symmetry, texture and color. Another treatment option would be through orthodontic treatment. However, the patient found his narrow teeth, opting for increase teeth width.

To obtain excellent smile esthetics, the colors of the composite resin were selected according to the different polychromatic areas of the teeth and were inserted incrementally $[22,23]$.

Final polishing was performed 7 days after the restorative procedure, based on the premise that the entire resin is not fully polymerized at the time of manufacture and will absorb water for at least 24 hours after completion [24]. The final finishing procedures are essential to prevent biofilm buildup, early change in the staining of the 
restorations and to ensure the brightness and smoothness of the restorations $[5-7,25]$.

\section{CONCLUSION}

The present clinical case illustrates the efficiency of the use of dental bleaching, lip frenectomy, the restorative procedure with composite resin, and the closure of diastema, aimed at the functional and esthetic correction of compromised smile.

\section{Collaborators}

FR GOYATÁ, concepts; design; definition of intellectual content; literature search; data acquisition and analysis; manuscript preparation, editing and review. LHG MARQUES, literature search; data acquisition and analysis; manuscript preparation, editing and review. A MORENO, concepts; design; definition of intellectual content; literature search; data analysis; manuscript preparation, editing and review. ID BARREIROS, concepts; design; definition of intellectual content; literature search; data acquisition and analysis; manuscript preparation, editing and review. JB NOVAES JÚNIOR, concepts; design; definition of intellectual content; literature search; data analysis; manuscript preparation, editing and review. SML GONTIJO, concepts; design; definition of intellectual content; literature search; data analysis; manuscript preparation, editing and review.

\section{REFERENCES}

1. Machado AW, Moon W, Campos E, Gandini LG. Influence of spacing in the upper lateral incisor area on the perception of smile esthetics among orthodontists and laypersons. J World Fed Orthod. 2013;2(4):e169-e174. https://doi.org/10.1016/j. ejwf.2013.09.003

2. Lakshmi S, Abraham A, Selvakumaran G, Sekar V, Annapoorni $\mathrm{H}$. Influence of aesthetic dental and facial measurements on patient satisfaction between genders in Indian patients. Tanta Dent J. 2015;12(3):197-202. https://doi.org/10.1016/j. tdj.2015.05.008

3. Celeste RK. Home Bleaching and in-office Bleaching may not be Equally Effective Clinically. J Evid Based Dent Pract. 2011;11(2):97-98. https://doi.org/10.1016/j. jebdp.2011.03.001

4. Wheeler B, Carrico CK, Shroff B, Brickhouse T, Laskin DM. Management of the Maxillary Diastema by Various Dental Specialties. J Oral Maxillofac Surg. 2018;76(4):709-715. https://doi.org/10.1016/j.joms.2017.11.024

5. Frese C, Schiller P, Staehle HJ, Wolff D. Recontouring teeth and closing diastemas with direct composite buildups: A 5-year follow-up. J Dent. 2013;41(11):979-985. https://doi. org/10.1016/j.jdent.2013.08.009

6. Wolff D, Kraus T, Schach C, Pritsch M, Mente J, Staehle HJ, et al. Recontouring teeth and closing diastemas with direct composite buildups: A clinical evaluation of survival and quality parameters. J Dent. 2010;38(12):1001-1009. https:// doi.org/10.1016/j.jdent.2010.08.017

7. Romero MF, Babb CS, Brenes C, Haddock FJ. A multidisciplinary approach to the management of a maxillary midline diastema: A clinical report. J Prosthet Dent. 2018;119(4):502-505. https://doi.org/10.1016/j.prosdent.2017.06.017

8. Lempel E, Lovász BV, Meszarics R, Jeges S, Tóth Á, Szalma J. Direct resin composite restorations for fractured maxillary teeth and diastema closure: A 7 years retrospective evaluation of survival and influencing factors. Dent Mater. 2017;33(4):467476. https://doi.org/10.1016/j.dental.2017.02.001

9. Lin J, Sun M, Zheng Z, Shinya A, Han J, Lin H, Zheng G, Shinya A. Effects of rotating fatigue on the mechanical properties of microhybrid and nanofiller-containing composites. Dent Mater J. 2013;32(3):476-83. https://doi.org/10.4012/dmj.2012-225

10. Souza-Gabriel AE, Vitussi LOC, Milani C, Alfredo E, Messias DCF, Silva-Sousa YTC. Effect of Bleaching Protocols with 38\% Hydrogen Peroxide and Post-Bleaching Times on Dentin Bond Strength. Braz Dent J. 2011;22(4):317-321. https://doi. org/10.1590/S0103-64402011000400010

11. Jhaveri H. The Aberrant Frenum. In: Dr. Hiral Jhaveri (ed), Dr. PD Miller the father of periodontal plastic surgery 2006;29-34.

12. Wyse CR. Simplified technique for rubber dam placement. Dental Digest. 1971;77(12):714-717.

13. Rechmann P, Bartolome N, Kinsel R, Vaderhobli R, Rechmann BMT. Bond strength of etch-and-rinse and self-etch adhesive systems to enamel and dentin irradiated with a novel CO2 9.3 $\mu \mathrm{m}$ short-pulsed laser for dental restorative procedures. Lasers Med Sci. 2017;32(9):1981-1993. https://doi.org/10.1007/ s10103-017-2302-y

14. Vaez SC, Correia ACC, Santana TR, Santana MLC, Peixoto AC, Leal PL, et al. Is a Single Preliminary Session of In-office Bleaching Beneficial for the Effectiveness of At-home Tooth Bleaching? A Randomized Controlled Clinical Trial. Oper Dent. 2019;44(4):E180-E189. https://doi.org/10.2341/18-196-c

15. Devishree, Gujjari SK, Shubhashini PV. Frenectomy: a review with the reports of surgical techniques. J Clin Diagn Res. 2012;6(9):1587-1592. https://doi.org/10.7860/ JCDR/2012/4089.2572

16. Vohra FA, Kasah K. Influence of bleaching and antioxidant agent on microtensile bond strength of resin based composite to enamel. Saudi J Dent Res. 2014;5(1):29-33. https://doi. org/10.1016/j.ksujds.2013.06.001

17. França Didier V, Ulisses Dantas Batista A, Viégas Montenegro R, Borges Fonseca R, Galbiatti de Carvalho F, de Barros S, et al. Influence of hydrogen peroxide-based bleaching agents on the bond strength of resin-enamel/dentin interfaces. Int J Adhes Adhes. 2013;47:141-145. https://doi.org/10.1016/j. ijadhadh.2013.08.009

18. Loomans BAC, Kreulen CM, Huijs-Visser HECE, Sterenborg BAMM, Bronkhorst EM, Huysmans MCDNJM, et al. Clinical 
performance of full rehabilitations with direct composite in severe tooth wear patients: 3.5 Years results. J Dent. 2018;70:97-103. https://doi.org/10.1016/j.jdent.2018.01.001

19. Mesko ME, Sarkis-Onofre R, Cenci MS, Opdam NJ, Loomans $B$, Pereira-Cenci T. Rehabilitation of severely worn teeth: $A$ systematic review. J Dent. 2016;48:9-15. https://doi.org/10. 1016/j.jdent.2016.03.003

20. Nandini S. Indirect resin composites. J Conserv Dent. 2010;13(4):184-194. http://www.jcd.org.in/text.asp?2010/ $13 / 4 / 184 / 73377$

21. Cunha LF, Caetano IM, Dalitz F, Gonzaga CC, Mondelli J. Cleidocranial Dysplasia Case Report: Remodeling of Teeth as Aesthetic Restorative Treatment. Case Reports in Dentistry. 2014, 5 pag. https://doi.org/10.1155/2014/901071

22. Wahbi MA, Al Sharief HS, Tayeb H, Bokhari A. Minimally invasive use of coloured composite resin in aesthetic restoration of periodontially involved teeth: Case report. Saudi Dent J. 2013;25(2):83-89. https://doi.org/10.1016/j. sdentj.2013.02.001
23. Buda M. Form and color reproduction for composite resin reconstruction of anterior teeth. Int J Periodontics Restorative Dent. 1994;14(1):34-47.

24. Lopes GC, Franke M, Maia HP. Effect of finishing time and techniques on marginal sealing ability of two composite restorative materials. J. Prosthet Dent. 2002;88(1):32-36. https://doi.org/10.1067/mpr.2002.127416

25. Ferreira PM, Souto SHA, Borges BCD, Assunção IVd, Costa GdFAd. Impact of a novel polishing method on the surface roughness and micromorphology of nanofilled and microhybrid composite resins. Rev Port Estomatol Med Dent Cir Maxilofac 2015;56)1):18-24. https://doi.org/10.1016/j. rpemd.2015.01.002
Received on: 6/2/2019

Final version resubmitted on: 4/4/2019

Approved on: 6/5/2019 